International Research Journal of Management, IT \& Social Sciences
Available online at https://sloap.org/journals/index.php/irjmis/
Vol. 6 No. 6, November 2019, pages: 87 94
ISSN: 2395-7492
https://doi.org/10.21744/irjmis.v6n6.765

\title{
The Reaction of Indonesian Capital Market to Political Event the Announcement of Indonesia Presidential Election 2019 Results (Event Study on KOMPAS 100)
}

Ni Made Dwita Ratnaningsih ${ }^{\text {a }}$ A.A.G.P. Widanaputra ${ }^{\text {b }}$

\section{Article history:}

Received: 27 June 2019

Accepted: 30 September 2019

Published: 15 October 2019

\section{Keywords:}

abnormal return; capital markets; event studies; Jokowi-Ma'aruf; political events;

\begin{abstract}
Political events, especially the General Election is one of the non-economic risks that can influence investors' decisions to invest in the capital market. Elections are closely related to the policies that will be implemented by the elected President thus the elections are important for investors as the considerations for investment. This study aimed to determine the reaction of the Indonesian capital market by testing the information content of political events the announcement of the presidential election 2019 results using event study. The population in this study was all the companies that are listed in Indonesia Index KOMPAS 100, the sample was taken by the saturated sample method. The hypothesis was tested with one-sample t-test. The announcement of the election results would contain the information that caused the market to react, as the evidenced there were significant abnormal returns occurred around the event window, and the average abnormal return that occurs was positive, thus the announced election results that Jokowi-Ma'aruf's victory was positively welcomed by the market.
\end{abstract}

2395-7492@ Copyright 2019. The Author. This is an open-access article under the CC BY-SA license (https://creativecommons.org/licenses/by-sa/4.0/) All rights reserved.

\section{Author correspondence:}

Ni Made Dwita Ratnaningsih,

Udayana University, Denpasar, Indonesia.

Email address: dwitaratnaningsih888@gmail.com

\section{Introduction}

The stock market has an important role in the financial market and plays an important role in the growth of a country's industry by providing optimal distribution of funds between users and investors. Stock market performance is influenced by economic and non-economic events. Non-economic events that affect capital market performance include environmental conditions, human rights issues, terrorist acts, demonstrations, and political events that are very sensitive to market conditions (Luhur, 2010). Political events are one of the non-economic risks that can influence investors' decisions to invest. There is an important relationship between stock market performance and political issues as non-economic factors in countries around the world.

${ }^{a}$ Udayana University, Denpasar, Indonesia

${ }^{\mathrm{b}}$ Udayana University, Denpasar, Indonesia 
Stable political conditions tend to improve economic performance, conversely political events that threaten national stability tend to get negative responses from investors' expectations of political events that occur will be reflected through fluctuations in share prices on the stock exchange (Yuliana, 2015; Intiana \& Sapiin, 2017). There are many endogenous and exogenous factors that can affect stock prices in the market but factors from the election also cause price fluctuations in the market, which shows that the political events of the election have a relationship and affect the movement of capital markets (Manukar et al., 2018; Setiawan et al., 2018). Of all political events, elections are considered to have the most influence on the capital market (Hung, 2013). Changes in the legislative and executive bodies are part of political events that can affect the economic regulation and conditions of the country.

The first Political and Stock Market Research Conducted by Niederhoffer et al., (1970), who analyzed market movements in the days and weeks related to the US presidential election. Several event studies have been conducted in various countries. Hung (2013); Pramana et al., (2019); Oehler et al., (2013), examined the general elections in the United States. Osuala et al., (2018) in Nigeria, Koilakiotis et al., (2016) in Greece, (Ahmad et al., 2013) and (Khan et al., 2018) in Pakistan. The results showed that elections taking place in these countries have a negative and positive effect on the capital market with the formation of significant abnormal returns around the window of events. In Indonesia, several study events are also conducted. Kurniawati et al., (2014); Pratam et al., (2015); Aggarwal (2017); Sihotang \& Mekel (2015), The results show that the Indonesian capital market reacts to election events, in which abnormal returns are formed, although the abnormal returns that are formed vary.

In Indonesia elections are held regularly once in five years. And throughout the history of each election period election events cause changes in IHSG (Indonesian composite stock price index), 2019 is a political year in Indonesia, in the 2019 election, the pair of candidates for president who came forward were only two candidate, the first candidate is Jokowi-Ma'aruf and and the second candidate is Prabowo-Sandi. The return of Jokowi as a presidential candidate was responded positively by the market, because of Joko Widodo's government policy so far that applies to the business world has the opportunity to remain the same in the future. (CNN, 2018). The election results can be information for investors to determine their attitude and decision in the capital market.

Based on the background and research that have been described previously, it is obtained that a political event, especially the events in the Presidential Election have an impact on stock price fluctuations that will ultimately affect the returns generated on investment in the capital market. The response generated in the capital market as a reaction from political information can be measured by the event study method. Therefore, researchers want to conduct research on the capital market reaction to the announcement of the Election Results of the President of the Republic of Indonesia in 2019 by testing the information content of the Kompas 100 index.

\section{Literature Review and Development of Hypothesis}

\section{Efficient Market Hypothesis}

According to Fama et al., (1969), which explains the efficient market theory that was published decades ago and widely used as literature states the main concept of the efficient market hypothesis. Fama came out with an efficient market hypothesis in 1969. The market is said to be efficient if there is no investor that can earn abnormal return in long term by using the existing trade mechanism. It means that the stock prices reflect the information available in the market. The market will quickly react based on the existing information and will readjust to reach the new equilibrium price. This kind of market can be said to be efficient.

\section{Business Politics Cycle}

The theory of the business political cycle proposed by Nordhaus (1975), regarding the partisan model explains that a politician who is already in power tries to please the voter group by continuing policies that are considered beneficial to the voters who are also part of the investor group.

\section{Abnormal Return}

When the new information is available on the financial markets, current prices are rapidly changing and are prices that reflect the actual information and conditions. Abnormal returns are sometimes triggered by "events." Price changes can be seen from the abnormal return that occurs, an announcement that contains information will provide an abnormal return to the market. Abnormal return or excess return is the excess of returns that actually occur against normal returns (Jogiyanto, 2017). 
Hypothesis 1a: There is a market reaction to the political event: the announcement of the 2019 Presidential Election results by a quick count

Hypothesis 1b: There is a market reaction to the political event: the announcement of the 2019 Presidential Election results by General Election Commissions (KPU).

\section{Materials and Methods}

\section{Population and Sample}

This research was conducted in Indonesia, in the companies registered in the KOMPAS 100 group on political events the announcement of the 2019 Presidential Election results in Indonesia. The technique used for sample selection was a saturated sample. The data used in this research were the secondary data in the form of a stock list, stock prices and the dates of the event.

\section{Research Period}

For event study, the research period was divided into two, which are window period and estimation period. The window period and estimation period for this research are as follows: While the sample was taken from the companies on KOMPAS 100. The data was collected from 15 October 2018- 11 April 2019 as the estimated period for quick count event and the event window was from 12 April 2019- 24 April 2019. The event results by KPU the data was collected from 13 November 2018- 15 November 2019 as the estimated period and the event window was from16 Mei $2019-24$ Mei 2019.

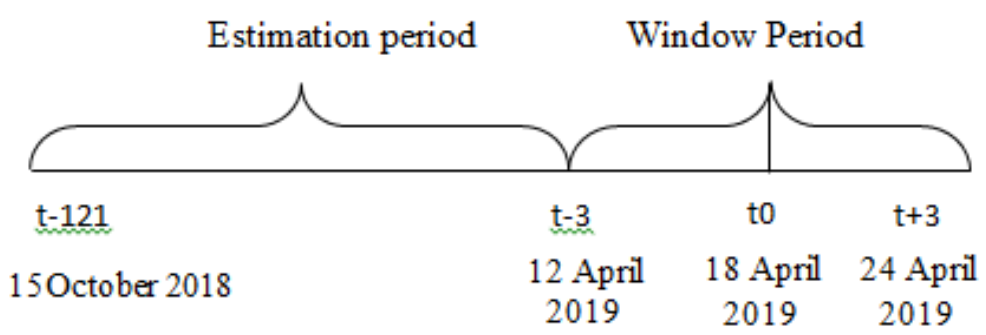

Figure 1. The Event Window for political event announcement election of result by quick count

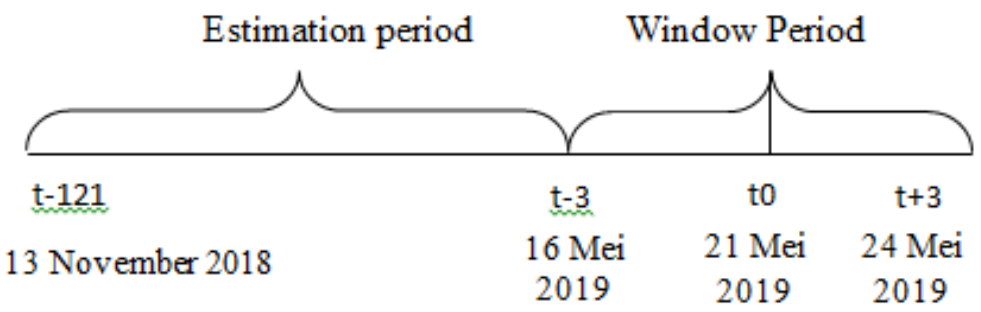

Figure 2. The Event Window for political event announcement election of result by KPU (General Election Commission)

\section{Hypothesis Testing}

Hypothesis 1a testing was aimed to examine the existence of abnormal return, that can be indicated for the information contained the even the announcement of the 2019 Presidential Election results by quick count, and Hypothesis $1 \mathrm{~b}$ for the even the announcement of the 2019 Presidential Election results by KPU(commission of general election). The hypothesis is tested with one-sample t-test with the hypothesis criteria, namely H1 is accepted if Sig $\leq 0.05$.

Ratnaningsih, N. M. D., \& Widanaputra, A. A. G. P. (2019). The reaction of Indonesian capital market to political event the announcement of Indonesia presidential election 2019 results. International Research Journal of Management, IT and Social Sciences, 6(6), 87-94. https://doi.org/10.21744/irjmis.v6n6.765 
- Actual Return

Rit $=($ Pit-Pit-1) $/($ Pit-1)

Rit $=$ Actual return in period

$\mathrm{Pit}=$ the stock price in $\mathrm{t}$-period

Pit-1 $=$ the stock price in before $\mathrm{t}$-period

- $\quad$ Expected Return

$\mathrm{E}(\mathrm{Ri}, \mathrm{t})=\frac{\sum_{j=t 1}^{t 2} R i, j}{T}$

$\mathrm{E}(\mathrm{Ri}, \mathrm{t})=$ expected return for stock $\mathrm{i}$ at period $\mathrm{t}$;

$\mathrm{Ri}, \mathrm{j}=$ Actual return in stock $\mathrm{i}$ at estimate period $\mathrm{j}$

$\mathrm{T}=$ period estimation 121 days

- Abnormal Return

ARi.t $=$ Ri.t - E (Ri.t)

ARit $=$ abnormal return of stock $\mathrm{i}$ at period $\mathrm{t}$; $\mathrm{Rit}=$ actual return of stock $\mathrm{i}$ at period $\mathrm{t}$; $\mathrm{E}(\mathrm{Rit})=$ expected return of stock $\mathrm{i}$ at period $\mathrm{t}$;

- Average Abnormal Return

$\mathrm{AARt}=\frac{\sum_{i=1}^{n} A R i, t}{n}$

AR $n=$ average abnormal return of stock $i$ at period $t$

ARit $=$ abnormal return of stock $i$ at period $t$;

$\mathrm{N}=$ number of samples;

\section{Results and Discussions}

\section{Descriptive Statistics Test Results}

Descriptive statistical calculations are performed on secondary data that has been processed include stock returns in the window period, stock returns in estimated period, and abnormal returns during the event period, namely for the announcement of the results of the election version of the quick count on April 12 2019-24 April 2019 (7 days) and the announcement of the election results by KPU on May 16, 2019 - May 24, 2019.

Table 1

Descriptive Statistics Test Results

\begin{tabular}{lll}
\hline Variabel & AAR & AAR \\
& KOMPAS 100 - QC & KOMPAS 100 - KPU \\
\hline Minimum & $-0,014096$ & $-0,029414$ \\
Maximum & 0,013277 & 0,021753 \\
Mean & 0,0010346 & 0,0048395 \\
Median & 0,0037327 & 0,011537 \\
Variance & 0,000 & 0,000 \\
Std.Deviation & 0,008735 & 0,0178323 \\
\hline
\end{tabular}

The table above shows descriptive statistics on the average abnormal returns of KOMPAS 100 during the election announcement period. The value of standard deviation is 0.008735 for the announcement of the results of the quick count and the average is 0.0010346 and for the standard deviation value of 0.008735 , the data that been used varied because the deviation value is greater than the mean value, then for the median value is 0.0037327 , and the minimum AAR is -0.014096 and the maximum AAR is 0.013277 . Furthermore, for the announcement of the election results by KPU showed the standard deviation value is 0.0178323 and the mean AAR KOMPAS 100 throughout the event period is 0.0048395 because the standard deviation value is greater than the mean value, the data that been used were varies, the median 0.011537 and the minimum AAR followed by a maximum of -0.029414 and 0.021753 . 
Based on statistical the results of the average abnormal returns during the event period has a positive value. The positive average abnormal return shows that during the event period, the market positively welcomed the results of the presidential election both the results issued by the survey agency through the quick count and the announcement made by the KPU which won the first presidential candidate as the elected president of the Indonesia 2019- 2024.

Hypothesis Testing Results

Table 2

Abnormal return test: Announcement of Election Result by quick count

\begin{tabular}{lllll}
\hline Period & Date & AAR & Sig & Results \\
\hline t-3 & 12 April 2019 & $-0,004956$ & 0,018 & Significant \\
t-2 & 15 April 2019 & 0,004671 & 0,031 & Significant \\
t-1 & 16 April 2019 & 0,005419 & 0,014 & Significant \\
t & 18 April 2019 & 0,003732 & 0,181 & Not Significant \\
t+1 & 22 April 2019 & $-0,014095$ & 0,000 & Significant \\
t+2 & 23 April 2019 & 0,013277 & 0,000 & Significant \\
t+3 & 24 April 2019 & $-0,000805$ & 0,730 & Not Significant \\
\hline
\end{tabular}

One sample t-test results showed that there is a significant abnormal return on most days in the period of the announcement of the results of the quick count which is indicated by a significance value $<0.05$. One sample t-test was conducted to test the existence of information content on events. The majority of average abnormal returns in the testing period for the announcement of the election results in the quick count showed positive results with the highest AAR occurring at $t+2$ of 0.013277 , while the lowest AAR resulted in a negative AAR occurring at $t+1$ namely 0.014095. During the event period there are 5 days out of 7 days window period which produces a significant market reaction in the form of abnormal returns, namely at $\mathrm{t}-3, \mathrm{t}-2, \mathrm{t}-1, \mathrm{t}+1$, and $\mathrm{t}+2$.

The negative average abnormal return that occurred especially in the period of 3 days before the event ( $t-3)$, was assumed to occur due to an unstable political situation in the community due to the emergence of many hoax news related to the general election. The negative AAR value that occurs specifically at $t+1$ and continues until $t+2$ is caused by a declaration of victory made by second candidate Prabowo-Sandi where the quick count results displayed by several survey institutions show the opposite that the first candidate Jokowi- Ma'ruf is leading the vote, so this is indicated as an unstable condition and is responded negatively by investors who produce negative AAR.

The abnormal returns positive and significant to events occurred on days $\mathrm{t}-2, \mathrm{t}-1$ and $\mathrm{t}+2$ respectively were $0.004671,0.005419$ and 0.013277 . The average abnormal return which is significant at $\mathrm{t}-1$ of 0.005419 shows that investors responded positively about the prediction of the winner of the election, this can be seen from the JokowiMa'aruf electability survey which has an electability value or a higher selectivity level than Prabowo-Sandi.

The emergence of an average abnormal return that was significant around the date of the event, it showed the market reacted to the event. Capital market reactions occur because the event had the information contained. The average abnormal return generated during the event period had a positive value, it is indicating that the market reacts to the announcement of the election results by quick count and the positive abnormal results generated are positive indicating that the quick count results that favoring the first candidate; Jokowi's Ma'aruf was welcomed positively by the market.

Table 3

Abnormal return test: Announcement of Election Result by general election commission

\begin{tabular}{lllll}
\hline Period & Tanggal & AAR & Sig & Keterangan \\
\hline $\mathrm{t}-3$ & 12 April 2019 & $-0,004956$ & 0,018 & Significant \\
$\mathrm{t}-2$ & 15 April 2019 & 0,004671 & 0,031 & Significant \\
$\mathrm{t}-1$ & 16 April 2019 & 0,005419 & 0,014 & Significant \\
$\mathrm{t}$ & 18 April 2019 & 0,003732 & 0,181 & Not Significant \\
$\mathrm{t}+1$ & 22 April 2019 & $-0,014095$ & 0,000 & Significant \\
$\mathrm{t}+2$ & 23 April 2019 & 0,013277 & 0,000 & Not Significant \\
$\mathrm{t}+3$ & 24 April 2019 & $-0,000805$ & 0,730 & Not Significant \\
\hline
\end{tabular}

Ratnaningsih, N. M. D., \& Widanaputra, A. A. G. P. (2019). The reaction of Indonesian capital market to political event the announcement of Indonesia presidential election 2019 results. International Research Journal of Management, IT and Social Sciences, 6(6), 87-94. https://doi.org/10.21744/irjmis.v6n6.765 
In table 3 for the results of the one sample t-test, the highest average abnormal return occurred on the second day after the event date $(t+2)$ is 0.021752 and the lowest on the $t-3$ is -0.028414 . Then there are four days that produce a significant abnormal return are on days $\mathrm{t}-3, \mathrm{t}-1, \mathrm{t}$ and $\mathrm{t}-2$. Three of the four days that produced a significant abnormal return on events had a positive average abnormal return that occurred in the $\mathrm{t}-1, \mathrm{t}$ and $\mathrm{t}+2$ respectively 0.014458 , 0.0192361 and 0.021752 . And at $\mathrm{t}-3$ the negative return generated is negative with AAR of -0.028414 .

The negative average abnormal return that occurred on $\mathrm{t}-3$ is indicated to occur because the market is still waiting for the certainty of the election results to be issued by the KPU, because so far there has been disagreement on the part of the second candidate regarding the results of the quick count that has been displayed by the survey institute, so that approaching the announcement date, the investor still sees that the dispute and the conditions encountered have not yet given concrete aim for investors to give a positive response to the political events of the announcement of the election results. Then the difference in response between the two camps led to the issue of holding a demonstration on the date that an official announcement would be made by the KPU.

Then at $\mathrm{t}-1$ a significant positive abnormal return is formed at 0.014458 , the abnormal return on the day before the event date shows that the market has begun to respond to the election results, because the final election results are already visible from the results of the national vote calculation conducted by the KPU which is displayed transparently and can be accessed directly on the official website. The market forming a positive average abnormal return shows that the results of the election vote calculation by the KPU which shows the vote acquisition favoring first candidate Jokowi-Ma'aruf is good news for investors and this continues until the next day on the event date.

On the event date on May 21, 2019 (t) the market gave a reaction in the form of a significant positive abnormal return of 0.0192361 . The market reaction is indicated by the existence of a significantly positive average abnormal return, which means the market reacts positively to the announcement of election results conducted by the KPU. The outcome decision by the KPU is what the public has been waiting for, especially for investors to determine their decisions. The official results announced by the KPU are expected to be an answer to the uncertainty that has occurred for a month regarding the results of the quick count and various types of disputes related to election results and decisions based on national vote counts.

Based on statistical results and testing one sample t-test showed that there was a significant abnormal return around and at the event date which can then be drawn conclusions on the announcement of election results conducted by the $\mathrm{KPU}$ that the $\mathrm{H} 1 \mathrm{~b}$ hypothesis is accepted and $\mathrm{HO}$ is rejected, which means that on the announcement of the election results by the KPU it contains information that causes the market to react and a significant positive abnormal return occurred indicated that Jokowi-Ma'aruf's victory as a good information for investors and is positively welcomed.

The results showed the same results as some previous studies related to the market reaction to political events, especially elections on capital markets in several countries in the world. Ur Rehman \& Khan (2015) in Pakistan, Oehler et al., (2013) in America, Gatumo (2017) in Kenya, Koilakiotis et al., (2016) in Greece, and some research in Indonesia by Melati \& Widiartanto (2014); Chandra (2015); Kurniawati et al., (2014).

\section{Conclusion}

The capital market reacted to politic events including political events the announcement of the results by quick count and the announcement of election results by the KPU. The announcement of the election results by quick count and by KPU had the same results, the results showed that the events have information content that causes the market reacted and it has been proven by the abnormal returns that occurred around the period of the event window. The abnormal return that occurred has positive and negative value. The negative abnormal return occurs because of the black campaign and hoax news, and the declaration of victory by the second candidate that they have different results from a quick count survey. The uncertain conditions and the conflict are seen as bad news by investors.

However, overall the average abnormal return that is formed has a positive significant value that the announced election results both the results of the quick count and the official announcement by the KPU which states that the calculation results showed the victory of Jokowi and Ma'aruf as president and the vice president for the next five years is considered to contain a good information which is then reacted positively by investors.

The data in this study use the adjusted closing price, the recommendation for further research can compare with the closing price thus we could see a comparison of the two data after analysis, then for the calculate expected return in this study using the mean adjusted model, there are still two models proposed by Brown \& Warner (1985), the market model and the market adjusted model. 
Conflict of interest statement

The authors declared that they have no competing interests.

Statement of authorship

The authors have a responsibility for the conception and design of the study. The authors have approved the final article.

Acknowledgments

We thank the editor of IRJMIS for their valuable time, support and advice.

Ratnaningsih, N. M. D., \& Widanaputra, A. A. G. P. (2019). The reaction of Indonesian capital market to political event the announcement of Indonesia presidential election 2019 results. International Research Journal of Management, IT and Social Sciences, 6(6), 87-94. https://doi.org/10.21744/irjmis.v6n6.765 


\section{References}

Aggarwal, R. (2017). Different avenues of capital market (secondary market) available for investing in market of yamuna nagar. International Research Journal of Management, IT and Social Sciences, 4(3), 34-50.

Ahmad, W., Sehgal, S., \& Bhanumurthy, N. R. (2013). Eurozone crisis and BRIICKS stock markets: contagion or market interdependence?. Economic Modelling, 33, 209-225. https://doi.org/10.1016/j.econmod.2013.04.009

Chandra, T. (2015). Impacts of Indonesia's 2014 Presidential Election towards Stock Priceso Indonesia Stock Exchange. International Journal of Business and Management, 10(7), 172. https://doi.org/10.5539/ijbm.v10n7p172

Fama, E. F., Fisher, L., Jensen, M. C., \& Roll, R. (1969). The adjustment of stock prices to new information. International economic review, 10(1), 1-21. https://doi.org/10.2307/2525569

Gatumo, F. M. How Do Initil Public Offerings Perform In Kenya? An Analysis of Offer and Closing Prices.

Hung, L. C. (2013). US Presidential Elections and the Taiwanese Stock Market. Issues \& Studies, 49(1).

Intiana, S. R. H., \& Sapiin, -. (2017). The affix me-/-kan and me(n)-/-kan in the presidential candidates' debate texts in 2014 - 2019: morphology observation on derivation and inflection. International Journal of Linguistics, Literature and Culture, 3(2), 66-77.

Jogiyanto, H. M. (2017). Analisis dan Desain (Sistem Informasi Pendekatan Terstruktur Teori dan Praktek Aplikasi Bisnis). Penerbit Andi.

Khan, M. W., Wang, J., Ma, M., Xiong, L., Li, P., \& Wu, F. (2018). Optimal energy management and control aspects of distributed microgrid using multi-agent systems. Sustainable Cities and Society. https://doi.org/10.1016/j.scs.2018.11.009

Koulakiotis, A., Papapanagos, H., \& Papasyriopoulos, N. (2016). Political elections, abnormal returns and stock price volatility: the case of Greece. Investment Management \& Financial Innovations, $13(1)$, 161. http://dx.doi.org/10.21511/imfi.13(1-1).2016.03

Kurniawati, E., Rohman, A., \& Triyana, K. (2014). Analysis of lard in meatball broth using Fourier transform infrared spectroscopy and chemometrics. Meat Science, 96(1), 94-98. https://doi.org/10.1016/j.meatsci.2013.07.003

Luhur, S. (2010). Reaksi pasar modal Indonesia seputar pemilihan umum 8 Juli 2009 pada saham LQ-45. Jurnal Keuangan dan Perbankan, 14(2), 249-262.

Manurkar, P., Stevenson, S., Khader, I., Deschênes, J. D., Swann, W. C., Newbury, N. R., \& Sinclair, L. C. (2018, September). Progress towards a three-node free-space clock network. In Frontiers in Optics (pp. FTh3C-4). Optical Society of America. https://doi.org/10.1364/FIO.2018.FTh3C.4

Melati, D. A., Saryadi, S., \& Widiartanto, W. (2015). Analisis Reaksi Pasar Modal Atas Peristiwa Pemilihan Presiden 9 Juli 2014 (Event Study Pada Indeks Saham Lq-45). Jurnal Ilmu Administrasi Bisnis, 4(2), 284-294.

Niederhoffer, V., Gibbs, S., \& Bullock, J. (1970). Presidential elections and the stock market. Financial Analysts Journal, 111-113.

Nordhaus, W. D. (1975). The political business cycle. The review of economic studies, 42(2), 169-190. DOI: https://doi.org/10.2307/2296528

Oehler, A., Walker, T. J., \& Wendt, S. (2013). Effects of election results on stock price performance: evidence from 1980 to 2008. Managerial Finance, 39(8), 714-736. https://doi.org/10.1108/MF-May-2012-0126

Osuala, A. E., Onoh, U. A., \& Nwansi, G. U. (2018). Presidential Election Results and Stock Market Performance: Evidence From Nigeria. Applied Economics and Finance, 5(2), 117-124. https://doi.org/10.11114/aef.v5i2.3016

Pramana, Y., Suprasto, H. B., Putri, I. G. A. M. D., \& Budiasih, I. G. A. N. (2019). Fraud factors of financial statements on construction industry in Indonesia stock exchange. International Journal of Social Sciences and Humanities, 3(2), 187196. https://doi.org/10.29332/ijssh.v3n2.313

Pratama, I. G. B., Sinarwati, N. K., Darmawan, N. A. S., \& SE, A. (2015). Reaksi pasar modal indonesia terhadap peristiwa politik (Event study pada peristiwa pelantikan Joko Widodo sebagai presiden Republik Indonesia ke-7). JIMAT (Jurnal Ilmiah Mahasiswa Akuntansi) Undiksha, 3(1). http://dx.doi.org/10.23887/jimat.v3i1.4754

Rehman, S., \& Khan, J. (2015). Impact of Political Event, Terrorist Attack and Natural Catastrophe on Stock Price returns: Evidence from Pakistan. Global Management Journal for Academic \& Corporate Studies, 5(1), 69.

Setiawan, I., Laksana, I. K. D., Mahyuni, -, \& Udayana, I. N. (2018). System of modality on the text of Indonesian presidential candidates debate on the period of 2014-2019. International Journal of Social Sciences and Humanities, 2(1), 157-170. https://doi.org/10.29332/ijssh.v2n1.121

Setiawan, I., Laksana, I. K. D., Mahyuni, -, \& Udayana, I. N. (2018). Transitivity in the text of Indonesian presidential candidates debate. International Research Journal of Management, IT and Social Sciences, 5(6), 114-130. https://doi.org/10.21744/irjmis.v5n6.428

Sihotang, E. M., \& Mekel, P. A. (2015). Reaksi Pasar Modal Terhadap Pemilihan Umum Presiden Tanggal 9 Juli 2014 Di Indonesia. Jurnal EMBA: Jurnal Riset Ekonomi, Manajemen, Bisnis dan Akuntansi, 3(1).

Yuliana, Y. T. (2015). Reaksi pasar saham terhadap peristiwa politik di parlemen Indonesia tahun 2014 (studi peristiwa pada perusahaan yang terdaftar di BEI) (Doctoral dissertation, Universitas Airlangga). 